Article

\title{
Effect of Carbon Additives on the Electrochemical Performance of $\mathrm{Li}_{4} \mathrm{Ti}_{5} \mathrm{O}_{12} / \mathrm{C}$ Anodes
}

\author{
Irina Stenina ${ }^{1}$, Ruslan Shaydullin ${ }^{1,2}$, Tatiana Kulova ${ }^{3}$, Anna Kuz'mina ${ }^{3}$, \\ Nataliya Tabachkova 4,5 (D) and Andrey Yaroslavtsev $1, *(\mathbb{D})$ \\ 1 Kurnakov Institute of General and Inorganic Chemistry of the Russian Academy of Sciences, \\ Leninsky prospekt 31, 119991 Moscow, Russia; irina_stenina@mail.ru (I.S.); carbanod@mail.ru (R.S.) \\ 2 Department of Chemistry, Lomonosov Moscow State University, 119991 Moscow, Russia \\ 3 Frumkin Institute of Physical Chemistry and Electrochemistry of the Russian Academy of Sciences, \\ Leninsky prospekt 31-4, 119071 Moscow, Russia; tkulova@mail.ru (T.K.); nyurka_92@mail.ru (A.K.) \\ 4 Prokhorov General Physics Institute of the Russian Academy of Sciences, 38, Vavilov Str., \\ 119991 Moscow, Russia; ntabachkova@gmail.com \\ 5 Department of Materials Science of Semiconductors and Dielectrics, National University of Science and \\ Technology (MISIS), 119049 Moscow, Russia \\ * Correspondence: yaroslav@igic.ras.ru; Tel.: +7-495-952-2487
}

Received: 26 June 2020; Accepted: 29 July 2020; Published: 1 August 2020

check for updates

\begin{abstract}
The $\mathrm{Li}_{4} \mathrm{Ti}_{5} \mathrm{O}_{12} / \mathrm{C}$ composites were prepared by a hydrothermal method with in situ carbon addition. The influence of the morphology and content of various carbon materials (conductive carbon black, mesoporous carbon G_157M, and carbon replicas) on the electrochemical performance of the $\mathrm{Li}_{4} \mathrm{Ti}_{5} \mathrm{O}_{12} / \mathrm{C}$ composites was investigated. The obtained composites were characterized using X-ray diffraction, scanning electron microsopy, high-resolution transmission electron microscopy, thermogravimetric analysis, Raman spectroscopy, and $\mathrm{N}_{2}$ sorption-desorption isotherms. Morphology of the $\mathrm{Li}_{4} \mathrm{Ti}_{5} \mathrm{O}_{12} / \mathrm{C}$ composites depends on the carbon matrix used, while both morphology and the amount of carbon material have a great impact on the rate capability and cycling stability of the obtained composites. At low current densities, the $\mathrm{Li}_{4} \mathrm{Ti}_{5} \mathrm{O}_{12} / \mathrm{C}$ composite with 5 wt.\% G_157M exhibits the highest discharge capacity, while at high charge-discharge rates, the $\mathrm{Li}_{4} \mathrm{Ti}_{5} \mathrm{O}_{12} /$ carbon black composites show the best electrochemical performance. Thus, at $\sim 0.1 \mathrm{C}, 5 \mathrm{C}$, and $18 \mathrm{C}$ rates, the discharge capacities of the obtained $\mathrm{Li}_{4} \mathrm{Ti}_{5} \mathrm{O}_{12} / \mathrm{C}$ composites are 175, 120, and $70 \mathrm{mAh} / \mathrm{g}$ for G_157M, 165,126 , and $78 \mathrm{mAh} / \mathrm{g}$ for carbon replicas, and 173, 128, and $93 \mathrm{mAh} / \mathrm{g}$ for carbon black. After 100 cycles, their capacity retention is no less than $95 \%$, suggesting their promising application perspective.
\end{abstract}

Keywords: lithium ion battery; $\mathrm{Li}_{4} \mathrm{Ti}_{5} \mathrm{O}_{12} ;$ mesoporous carbon; carbon replica

\section{Introduction}

In recent years, lithium titanate with a spinel structure $\left(\mathrm{Li}_{4} \mathrm{Ti}_{5} \mathrm{O}_{12}, \mathrm{LTO}\right)$ has been considered as a promising anode material for high-power applications in lithium-ion batteries, such as electric vehicles and backup power systems. LTO exhibits an exceptional stability and a long lifetime cycling due to a near zero lattice volume change $(<1 \%)$ during the lithium insertion-extraction process [1,2], which is 13 times less than that of graphite, widely used as an anode material in commercial lithium-ion batteries [3,4]. Compared with graphite, lithium titanate has a flat and relatively high operating potential of about $1.55 \mathrm{~V}$ (vs. $\mathrm{Li} / \mathrm{Li}^{+}$), which results in a decreased cell potential, avoiding an undesired reduction (decomposition) of most electrolyte solvents with the SEI (solid electrolyte interface) formation [2,5]. However, the main disadvantage that restricts the wide practical use of lithium titanate is its poor rate capability caused by its low electronic conductivity $\left(-10^{-13} \mathrm{~S} / \mathrm{cm}\right)$ and lithium ion diffusion coefficient $\left(-10^{-12} \mathrm{~cm}^{2} / \mathrm{s}\right)[2,6]$. 
The electrochemical properties of lithium titanate largely depend on the synthesis method. The solid-state reaction is the most common method, due to its simplicity and scalability $[7,8]$. However, long-term high-temperature annealing is required $\left(>15 \mathrm{~h}\right.$ at $\left.850-1000{ }^{\circ} \mathrm{C}\right)$ due to a low rate of the solid-state reaction, determined by the slow ion diffusion in solids. This inevitably leads to the production of micron-sized lithium titanate particles with a high aggregation degree $[9,10]$. Attempts to reduce particle size by decreasing the sintering temperature often lead to the formation of $\mathrm{Li}_{2} \mathrm{TiO}_{3}$ and $\mathrm{TiO}_{2}$ impurities [11,12].

The hydrothermal process seems to be a promising alternative to the solid-state method, due to softer reaction conditions, the possibility of preparation of nanosized LTO with various morphologies, and high phase purity [13-15]. The resulting materials usually exhibit significantly higher discharge capacities and better cyclability compared to those synthesized by the solid-state method [15-17].

Several approaches have been proposed to improve the electrochemical properties of electrode materials, which include heterovalent doping [18-21], synthesis of nanostructured materials [16,22-25], and formation of composites with highly conductive additives and/or carbon coating [26-29]. At the same time, for preparing electrodes for lithium-ion batteries, highly conductive additives (e.g., carbon black) are used with a binder to ensure good conductive contacts between the particles. It results in the increased transfer of both electrons and lithium ions at the interfaces, while its transfer inside the particles themselves turns out to be a limiting stage. Synthesis of lithium titanate in the presence of highly conductive materials can limit its particle growth, change the morphology, lead to a more homogeneous material, and thus improve its electrochemical performance [30-33]. In recent years, carbon nanotubes (CNTs) and graphene have been widely used as carbon additives, providing good contact between particles and high conductivity at the interfaces [34-38]. However, these composites are prepared, as a rule, by solid state reaction (mechanical mixing with carbon materials (first of all, carbon nanotubes, graphene, reduced graphene oxide, etc.) followed by high-temperature treatment) or annealing with various organic compounds (carbon precursors). Carbon materials with a large surface area, in particular, mesoporous carbons $[32,39,40]$, are also attractive. Simplicity of their synthesis compared to carbon nanotubes and graphene, the uniformity of their porous structure, and mechanical and thermal stability can be noted among their advantages [41-44]. The fabrication of the LTO composites with mesoporous carbons can lead to an additional decrease in the $\mathrm{Li}_{4} \mathrm{Ti}_{5} \mathrm{O}_{12}$ particle size, due to its formation in the pores of a carbon matrix, and an increase in the electrochemical stability and conductivity of the composite material. Modification (surface functionalization) of carbon materials, e.g., oxidation, allows improving their sorption ability. It is a simple way to generate functional groups of oxygen-containing groups, mainly carboxyl, carbonyl, and hydroxyl [45,46], which can act as adsorption centers, in particular, during hydrothermal synthesis of lithium titanate [47,48].

In this work, carbon materials with various morphologies and specific surface areas, including mesoporous carbon and one dimentional carbon materials, were used. $\mathrm{Li}_{4} \mathrm{Ti}_{5} \mathrm{O}_{12} /$ carbon material composites were prepared using a hydrothermal method and a subsequent low-temperature annealing. To ensure homogenization of carbon materials with the reaction solution and better binding of carbon to the $\mathrm{Li}_{4} \mathrm{Ti}_{5} \mathrm{O}_{12}$ particles, carbon materials were preliminarily oxidized with nitric acid. The effect of carbon morphology as well as its content on the electrochemical properties was studied and discussed.

\section{Materials and Methods}

Mesoporous carbon material G_157M (NanoTechCenter LLC, Tambov, Russia), carbon replicas (CR), prepared according to the procedure described elsewhere [49], and carbon black (CB, Timcal Graphite and Carbon, Switzerland) were used for the $\mathrm{Li}_{4} \mathrm{Ti}_{5} \mathrm{O}_{12} / \mathrm{C}$ composites synthesis. Carbon materials were pre-treated in concentrated nitric acid for $1 \mathrm{~h}$ and washed with deionized water. There are two main reasons for oxidizing the surface of carbon materials. The first was to impart the ability of carbon materials to form a colloidal solution in aqueous medium by attaching different functional groups directly to their surface. Moreover, the introduction of oxygen-containing groups onto the carbon surface was expected to facilitate the binding of carbon materials to lithium titanate. The 
predetermined amount of carbon in the $\mathrm{Li}_{4} \mathrm{Ti}_{5} \mathrm{O}_{12} / \mathrm{C}$ composites was 0,5 , or $20 \mathrm{wt}$. $\%$. The $\mathrm{Li}_{4} \mathrm{Ti}_{5} \mathrm{O}_{12} / \mathrm{C}$ composites were prepared hydrothermally using a previously developed procedure [50]. Firstly, the predetermined amount of pre-treated carbon material was ultrasonically dispersed in $0.5 \mathrm{M} \mathrm{LiOH}$ solution for $15 \mathrm{~min}$. Then, titanium butoxide was added dropwise in the molar ratio of $\mathrm{Li}: \mathrm{Ti}=3: 1$ under vigorous stirring. Next, the received suspension was transferred into a steel autoclave (Teflon-lined) and kept at $130^{\circ} \mathrm{C}$ for $12 \mathrm{~h}$. The resulting precipitate was washed with deionized water to remove $\mathrm{LiOH}$ excess, dried at $80^{\circ} \mathrm{C}$ for $12 \mathrm{~h}$ in air, ground, and calcined at $400{ }^{\circ} \mathrm{C}$ for $5 \mathrm{~h}$ in Ar atmosphere. The predetermined amount of carbon materials in the $\mathrm{Li}_{4} \mathrm{Ti}_{5} \mathrm{O}_{12} / \mathrm{C}$ composites was 0,5 , or $20 \mathrm{wt} . \%$. Hereinafter, the obtained composites were denoted as LTO/5\%G_157M, LTO/20\%CR, or LTO/5\%CB, etc., indicating the carbon material used and its predetermined amount. For comparison, a pure lithium titanate without the addition of carbon material was also prepared under the same synthesis conditions.

X-ray diffraction (XRD) measurements were performed using a Rigaku D/MAX 2200 diffractometer (Rigaku, Japan), $\mathrm{Cu}-\mathrm{K}_{\alpha}$ radiation. High-resolution transmission electron microscopy (HRTEM, Jeol JEM-2100, Jeol, Japan) and scanning electron microscopy (SEM, Carl Zeiss NVision 40 station) were used to observe the morphology and particle size of the samples. The amount of carbon materials was determined by thermogravimetric analysis (TGA) using a Netzsch TG 209 thermal balance (Netzsch, Germany) in Pt crucibles in air, at a heating rate of $10 \% \mathrm{~min}$. Specific surface areas were measured by $\mathrm{N}_{2}$ sorption-desorption at $-196{ }^{\circ} \mathrm{C}$ using a Sorbtometer-M specific surface area analyzer (Katakon LLC, Russia). The obtained data were analyzed using the Brunauer-Emmett-Teller (BET) model using a desorption branch in a relative pressure range of $0.05-0.25$. Before measurements, the samples were degassed at $200^{\circ} \mathrm{C}$ for $1 \mathrm{~h}$. Raman spectra of the samples were carried out on a DXRxi Raman Imaging Microscope with excitation by a laser line of $532 \mathrm{~nm}$. Fourier Transform Infrared (FTIR) spectra were recorded on a Nicolet iS5 FTIR spectrometer with a Specac Quest attachment (attenuated total reflection measurements).

Electrochemical properties of the $\mathrm{Li}_{4} \mathrm{Ti}_{5} \mathrm{O}_{12} / \mathrm{C}$ composites were measured in sealed three-electrode cells. Lithium foil was used as counter and reference electrodes. Working electrodes were prepared using a standard paste method. A slurry was prepared by mixing LTO or LTO/C composite (active material), a carbon black, and a polyvinylidene fluoride binder preliminary dissolved in anhydrous $\mathrm{N}$-methyl pyrrolidone in the ratio 80:15:5 (wt.\%). Mass loading of active material in each electrode was about $10-15 \mathrm{mg} / \mathrm{cm}^{2}$. The electrode paste was coated onto the stainless-steel gauze (current collector), pressed under $1000 \mathrm{~kg} / \mathrm{cm}^{2}$, and dried at $120^{\circ} \mathrm{C}$ in a vacuum. Assembly of the electrochemical cells was performed in an Ar-filled glove box. The electrolyte solution was 1 M LiPF6 in a mixture of ethylene carbonate, diethyl carbonate, and dimethyl carbonate (1:1:1 v/v). Galvanostatic charge-discharge tests were performed at different current densities in the range of $20-8000 \mathrm{~mA} / \mathrm{g}$ using a ZRU $50 \mathrm{~mA}-10 \mathrm{~V}$ workstation (JSC NTTs Buster, Russia). Specific discharge capacity was calculated per unit weight of LTO.

\section{Results}

Raman spectra of used carbon materials are shown in Figure 1. In the Raman spectra, two intense peaks attributed to the D- and G-bands were observed at $\sim 1340$ and $1600 \mathrm{~cm}^{-1}$, respectively. In carbonaceous materials, the G-band corresponds to the vibrational mode of carbon in $\mathrm{sp}^{2}$ hybridization (graphite), whereas the D-band indicates disorder and imperfection in the graphite structure [51,52]. However, the Raman spectra in this region cannot be fitted with only these two bands: at least four bands are necessary. Additional bands were observed at 1220 and $1530 \mathrm{~cm}^{-1}$, which could be attributed to the vibrations of $\mathrm{sp}^{3}$-hybridized carbon atoms of amorphous carbon [51,52].

In the Raman spectra of the $\mathrm{Li}_{4} \mathrm{Ti}_{5} \mathrm{O}_{12} / \mathrm{C}$ composites, the peaks at 225, 345, 420, 680, and $745 \mathrm{~cm}^{-1}$, assigned to the vibrations of $\mathrm{Li}-\mathrm{O}$ bonds in the $\mathrm{LiO}_{4}, \mathrm{LiO}_{6}$ polyhedra and $\mathrm{Ti}-\mathrm{O}$ bonds in $\mathrm{TiO}_{6}$ octahedra of lithium titanate $[33,53]$ were also observed in addition to the characteristic bands of carbon materials (Figure 1d). Their intensities are significantly higher than those of the D- and G-bands of carbon materials. At the same time, the Raman spectra of carbon-coated lithium titanate show an 
inverse ratio of these bands' intensities [54]. Thus, in the obtained composite materials, lithium titanate particles are most likely formed on the surface, rather than inside the pores of the carbon materials.

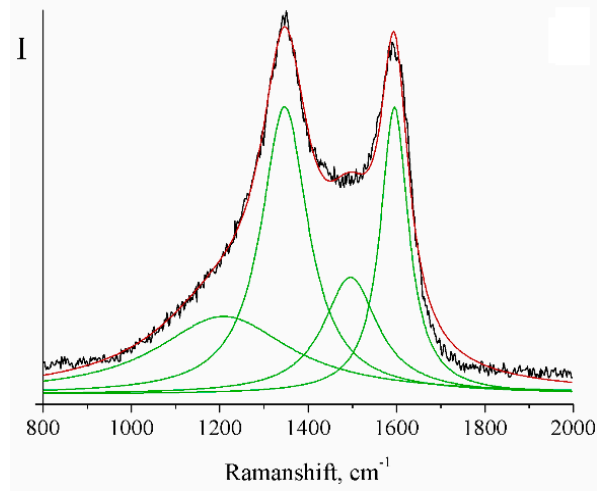

(a)

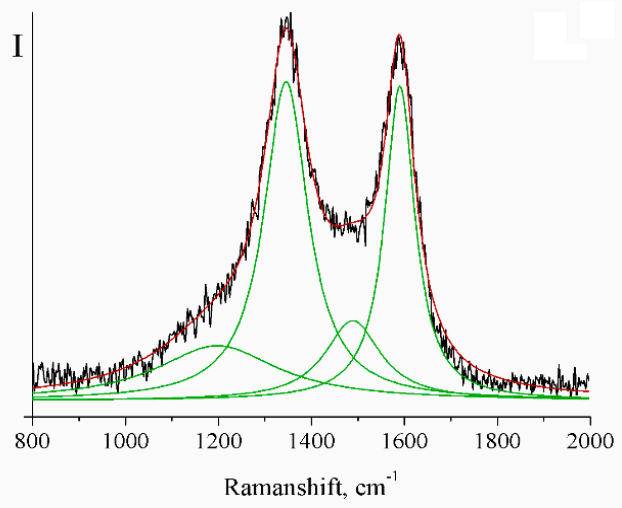

(c)

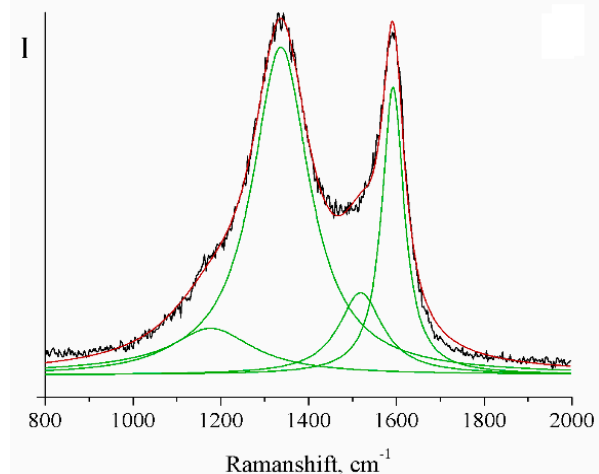

(b)

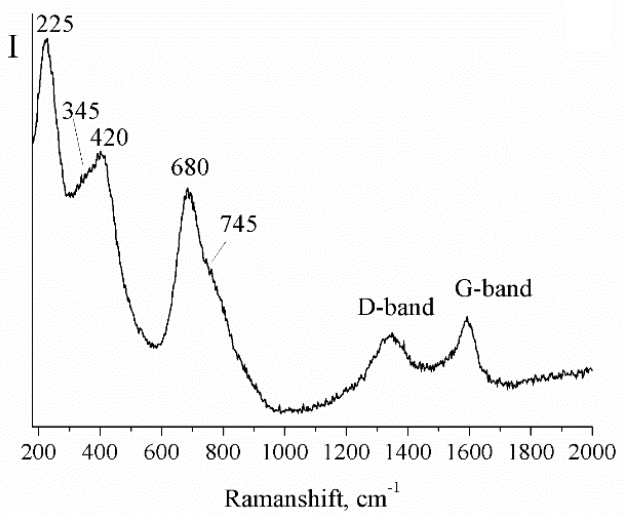

(d)

Figure 1. Raman spectra of the mesoporous carbon G_157M (a), carbon replica CR (b), carbon black $\mathrm{CB}(\mathrm{c})$, and the $\mathrm{LTO} / 5 \% \mathrm{CR}$ composite $(\mathbf{d})$.

The data of IR spectroscopy indicate the formation of a small number of oxygen-containing groups on the surface of carbonaceous materials during their oxidation. For example, the absorption in the region of $1720-1750 \mathrm{~cm}^{-1}$ can be attributed to the $>\mathrm{C}=\mathrm{O}$-groups, as in the case of the detonation nanodiamonds [46]. IR spectra of such materials have been widely discussed in the literature [55-59].

The thermogravimetric analysis (TGA) in air was performed to determine the carbon content in the as-prepared composites. According to the TGA data, the real carbon content in the obtained samples was slightly less than the predetermined value (Table 1).

Table 1. The crystallite size (coherent scattering region) of $\mathrm{Li}_{4} \mathrm{Ti}_{5} \mathrm{O}_{12}(\mathrm{~nm})$ and the real carbon content for the obtained samples.

\begin{tabular}{ccc}
\hline Sample & Crystallite Size (nm) & Real Carbon Content (wt.\%) \\
\hline LTO & 8.6 & - \\
LTO/5\%G_157M & 11.3 & 4.5 \\
LTO/20\%G_157M & 10.8 & 18.9 \\
LTO/5\%CR & 7.8 & 4.5 \\
LTO/20\%CR & 7.6 & 19.2 \\
LTO/5\%CB & 7.7 & 4.3 \\
LTO/20\%CB & 7.9 & 19.0 \\
\hline
\end{tabular}


In the X-ray diffraction patterns of all the composites obtained, the peaks at $2 \Theta=18.25^{\circ}, 35.43^{\circ}$, $43.22^{\circ}$, and $57.08^{\circ}$ correspond to the (111), (311), (400), and (333) reflections of the spinel $\mathrm{Li}_{4} \mathrm{Ti}_{5} \mathrm{O}_{12}$ (card No. 49-0207, base PDF-2) (Figure 2). At the same time, very weak reflections of $\mathrm{TiO}_{2}$ can also be observed for some samples. No diffraction peaks related to a graphite structure were observed, which may be due to its low content or X-ray amorphous form of carbon materials. The crystallite sizes (coherent scattering region) of the obtained samples calculated from the Scherrer formula are given in Table 1. The addition of carbon black and carbon replicas leads to a slight decrease in crystallite size, while the opposite tendency is observed when using mesoporous carbon. According to the data of experiments on low-temperature nitrogen adsorption, the BET specific surface area of the used carbon materials decreases in a series: mesoporous carbon G_157M > carbon replicas $\mathrm{CR}>$ carbon black CB (Table 2). On the one hand, the use of carbon materials with a larger surface area would lead to the formation of more dispersed lithium titanate particles. On the other hand, the availability of the surface and the concentration of sorption centers on it (mainly oxygen-containing functional groups-carboxyl, carbonyl, hydroxyl) formed after treatment by nitric acid are the main factors determining the nucleation and growth of the $\mathrm{Li}_{4} \mathrm{Ti}_{5} \mathrm{O}_{12}$ particles. The large surface area of the mesoporous carbon G_157M is primarily determined by a significant number of nanopores, the size range of which, according to the specification, is of $1-16 \mathrm{~nm}$. However, it seems that the LTO particles form on the outer surface of the carbon material rather than inside its pores. Moreover, a small number of sorption centers on its surface lead to the particle growth rather than to the formation of new ones. A slight decrease in the crystallite size with an increasing G_157M content up to $20 \%$, as well as Raman spectroscopy data, indirectly proves it. According to the $\mathrm{N}_{2}$ adsorption-desorption measurements, the total pore volume of the as-prepared carbon replicas is $0.3 \mathrm{~cm}^{3} / \mathrm{g}$ (Table 2), which along with surface area, suggests the CMK-3 type of this carbon material. A larger concentration of sorption centers on the surface of carbon black and carbon replicas results in more dispersed $\mathrm{Li}_{4} \mathrm{Ti}_{5} \mathrm{O}_{12}$ formation.

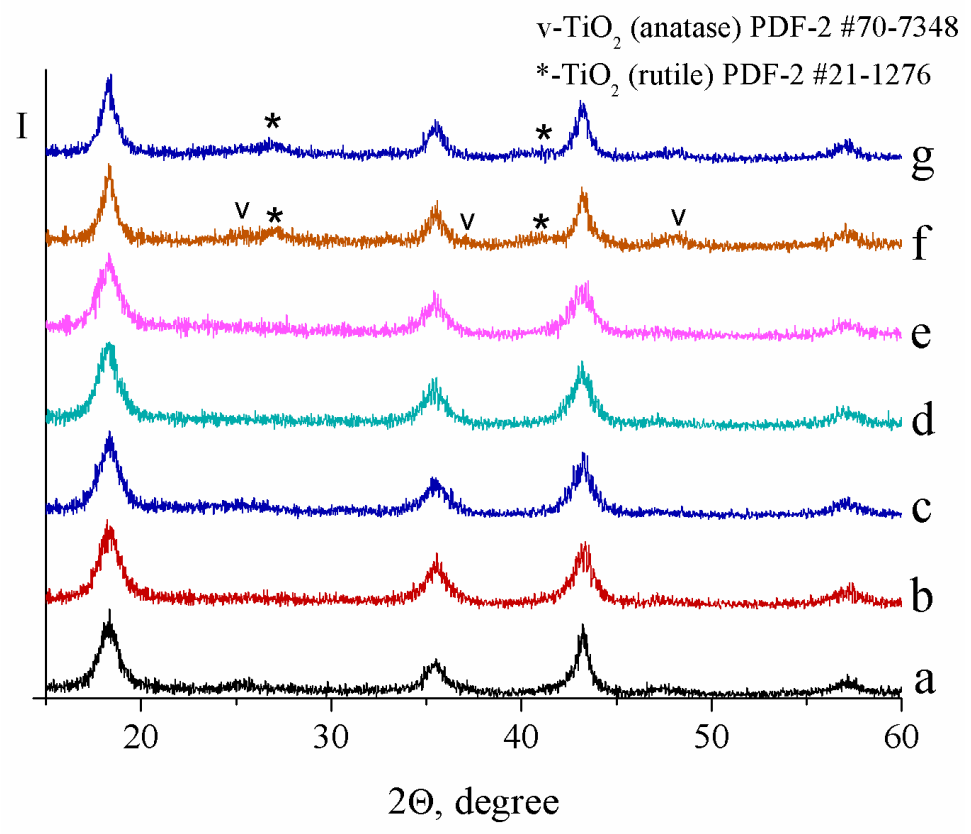

Figure 2. XRD patterns of LTO (a), LTO/5\%CB (b), LTO/20\%CB (c), LTO/5\%CR (d), LTO/20\%CR (e), LTO/5\%G_157M (f), and LTO/20\%G_157M (g).

Table 2. BET surface area and average pore size of the carbonaceous materials.

\begin{tabular}{cccc}
\hline Sample & Mesoporous Carbon G_157M & Carbon Replicas & Carbon Black \\
\hline BET surface area $\left(\mathrm{m}^{2} / \mathrm{g}\right)$ & 2225 & 662 & 60 \\
Average pore size $(\mathrm{nm})$ & 1.84 & 1.95 & 1.91 \\
Pore volume $\left(\mathrm{cm}^{3} / \mathrm{g}\right)$ & 1.027 & 0.318 & 0.029 \\
\hline
\end{tabular}


The SEM image of the $\mathrm{Li}_{4} \mathrm{Ti}_{5} \mathrm{O}_{12}$ (reference sample) shows spherical agglomerates with a diameter of about $2 \mu \mathrm{m}$ (Figure 3a). The agglomerates consist of nanosheets with a size of 50-70 nm by 100-200 nm and a thickness of 10-15 nm. The latter value is close to the crystallite size calculated from the XRD data. TEM images of this and other materials, in some cases, show atomic layers, mainly with an interlayer distance of $0.48 \mathrm{~nm}$, which corresponds to (111) lithium titanate reflection (Figure 3b).

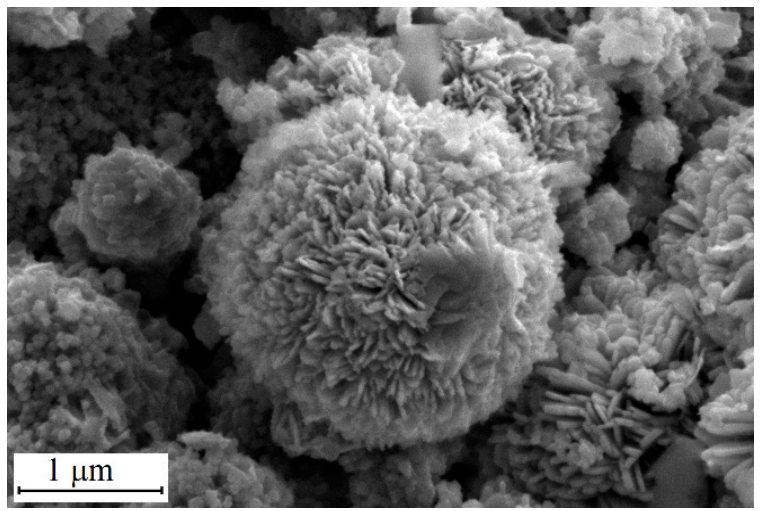

(a)

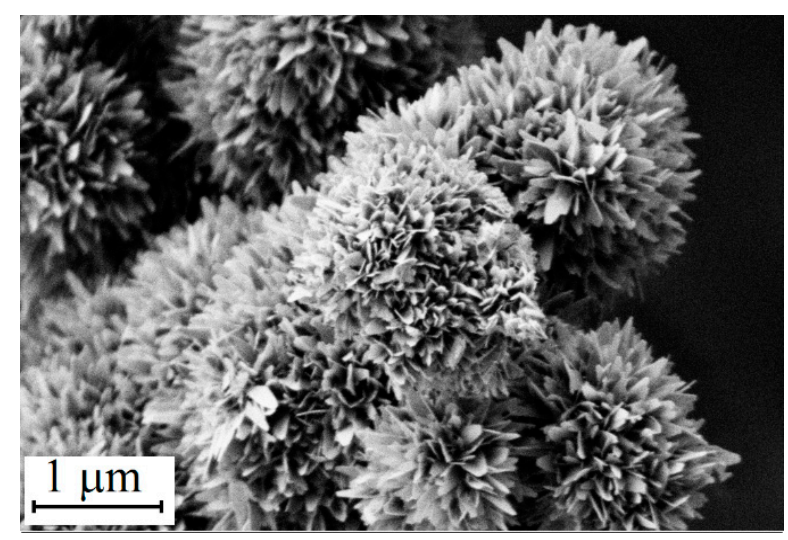

(c)

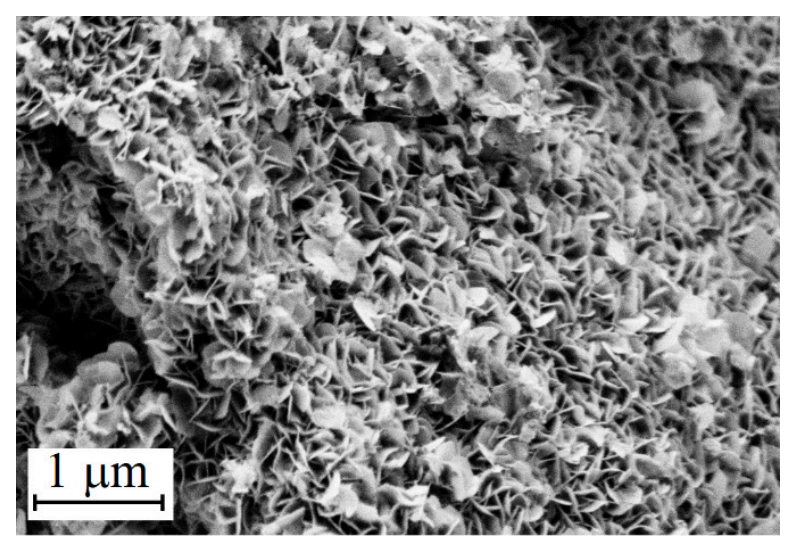

(e)

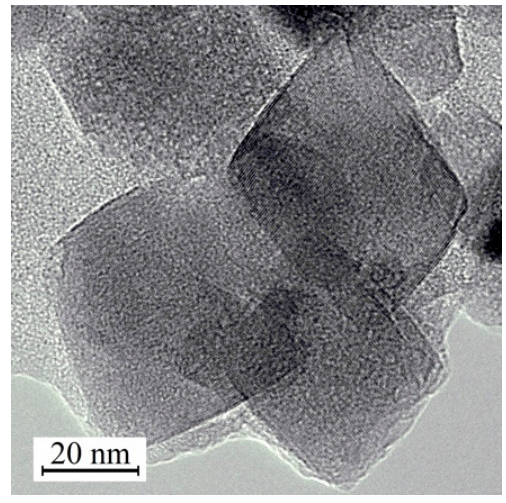

(b)

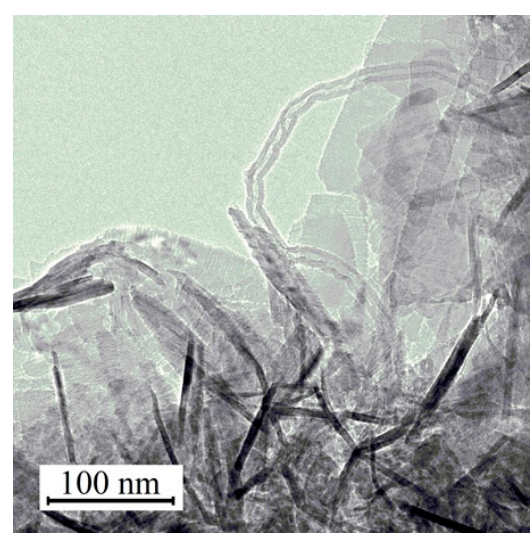

(d)

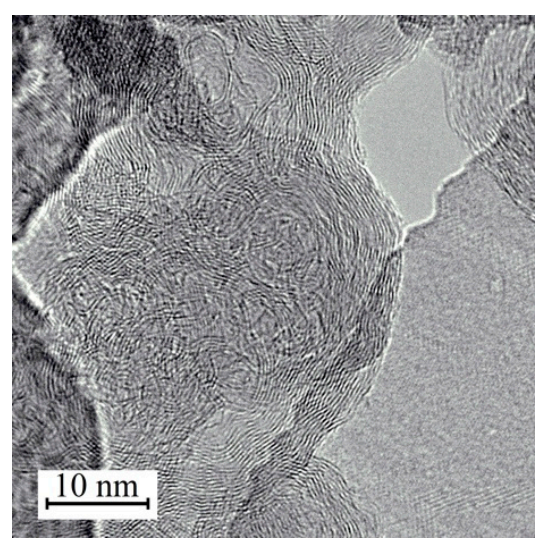

(f)

Figure 3. Cont. 


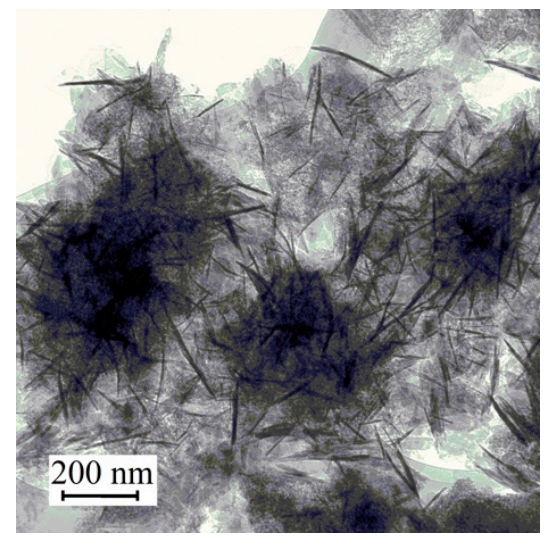

$(\mathrm{g})$

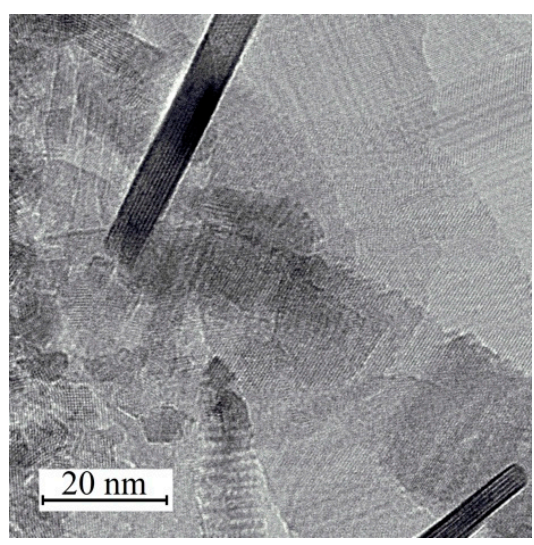

(h)

Figure 3. Scanning electron microscopy (SEM) (a,c,e) and transmission electron microscopy (TEM) $(\mathbf{b}, \mathbf{d}, \mathbf{f}-\mathbf{h})$ images of LTO (a,b), LTO/5\%G_157M (c,d), LTO/5\%CB (e,f), and LTO/5\%CR (g,h).

Carbon materials' addition during the LTO synthesis leads to some changes in the morphology of the obtained $\mathrm{Li}_{4} \mathrm{Ti}_{5} \mathrm{O}_{12} / \mathrm{C}$ composites (Figure 3c-h). In the case of the LTO/5\%G_157M sample, the spherical agglomerates also remain (Figure 3c). The TEM images, however, show carbon nanotubes (according to the specification, their content in the mesoporous carbon G_157M is $25-35 \mathrm{wt} . \%$ ), nanorods and particles with irregular shape, which are the components of the mesoporous carbon material G_157M interpenetrated into the $\mathrm{Li}_{4} \mathrm{Ti}_{5} \mathrm{O}_{12}$ nanoparticles (Figure 3d). In turn, the $\mathrm{Li}_{4} \mathrm{Ti}_{5} \mathrm{O}_{12}$ nanoparticles are grown on the carbon materials, indicating the strong interfacial interaction between them. It can be noted that in contrast to unmodified lithium titanate, the agglomerates of this composite remain even after ultrasonic dispersion during sample preparation for TEM.

The agglomerates of the $\mathrm{Li}_{4} \mathrm{Ti}_{5} \mathrm{O}_{12} / \mathrm{CB}$ composites have an irregular form, but they are composed of the same lithium titanate nanosheets (Figure 3e). Among them, there are rounded carbon black particles with a diameter of about 20-50 nm (Figure 3f).

Actually, the carbon replicas are not mesoporous materials, but are nanorods of 100-200 nm in length and 7-10 $\mathrm{nm}$ in diameter, formed after annealing of the sucrose sorbed in the mesoporous silica SBA-15. These dark nanorods are clearly seen among the agglomerates of the lithium titanate nanosheets (Figure 3g,h). Moreover, despite the developed surface, these nanorods are quite large and, unlike other materials, apparently do not form their own network. The difference in the morphology of the obtained composite materials is due to the influence of the carbon material morphology on the formation of $\mathrm{Li}_{4} \mathrm{Ti}_{5} \mathrm{O}_{12}$ particles.

Most carbon materials exhibit charge-discharge potentials between 0 and $1 \mathrm{~V}$. Therefore, their reversible electrochemical capacity in the cycling range of $\mathrm{Li}_{4} \mathrm{Ti}_{5} \mathrm{O}_{12}(1-3 \mathrm{~V})$ is relatively low. For example, in the case of carbon replicas (CR), its value does not exceed $20 \mathrm{mAh} / \mathrm{g}$. Therefore, the carbon material addition cannot increase the specific electrochemical capacity of the lithium titanate-based composites in this range of potentials. For all carbon materials, a significant contribution of the irreversible capacity was associated with the SEI formation [60-62] due to the partial electrolyte reduction in the first charge-discharge cycle.

The charge-discharge curves of the obtained $\mathrm{Li}_{4} \mathrm{Ti}_{5} \mathrm{O}_{12} / \mathrm{C}$ composites are typical for materials based on lithium titanate with a distinguished plateau at about $1.55 \mathrm{~V}$ (vs. $\mathrm{Li} / \mathrm{Li}^{+}$), indicating a two-phase process of $\mathrm{Li}_{4} \mathrm{Ti}_{5} \mathrm{O}_{12} \leftrightarrow \mathrm{Li}_{7} \mathrm{Ti}_{5} \mathrm{O}_{12}$ transformation (Figure 4). In all cases, a rather high irreversible capacity can be noted in the first charge-discharge cycle, e.g., it reaches $220 \mathrm{mAh} / \mathrm{g}$ for the LTO/5\%G_157M composite. From the tenth cycle, the Coulombic efficiency approaches $100 \%$ (the values of the discharge and charge capacities coincide), which suggests an industrially acceptable efficiency of these electrodes. The $\mathrm{Li}_{4} \mathrm{Ti}_{5} \mathrm{O}_{12}$ capacity usually turns out to be noticeably lower than 
the theoretical one $(175 \mathrm{mAh} / \mathrm{g})$, due to its rather low conductivity $[2,63]$. The specific capacity of $\mathrm{Li}_{4} \mathrm{Ti}_{5} \mathrm{O}_{12}$ was $164 \mathrm{mAh} / \mathrm{g}$ at a current density of $20 \mathrm{~mA} / \mathrm{g}$ and decreased markedly with an increase in the cycling rate (Figure 4). The use of the mesoporous carbon material G_157M and carbon black during the synthesis results in a significant increase in the capacity of composite materials in the entire range of current densities, e.g., at a current density of $20 \mathrm{~mA} / \mathrm{g}$, the discharge capacities of the LTO/5\%G_157M and LTO/5\%CB composites reach 175 and $174 \mathrm{mAh} / \mathrm{g}$, which are close to the theoretical value. The discharged capacity of the LTO/5\%CR sample remains almost at the same level as for the pure lithium titanate $(165 \mathrm{mAh} / \mathrm{g})$. Most likely, this is due to the absence of a continuous conducting network of carbon replicas, which is confirmed by electron microscopy data. At high current densities, the LTO/5\%CB sample shows the best performance (Figure 5). For example, its discharge capacity decreases by less than half at a $\sim 18 \mathrm{C}$ rate $(90 \mathrm{mAh} / \mathrm{g}, 1 \mathrm{C}=175 \mathrm{mAh} / \mathrm{g})$, and it is $68 \mathrm{mAh} / \mathrm{g}(39 \%$ of the theoretical capacity) at a $\sim 50 \mathrm{C}$ rate.

A good cycling stability was observed for all samples. At each current density, 5 charge-discharge cycles were recorded, which were well reproduced. Upon returning back to a current density of $20 \mathrm{~mA} / \mathrm{g}$ after 100 charge-discharge cycles at various rates, the capacity of all the studied materials decreases by no more than $5 \%$, which indicates excellent reversible stability.

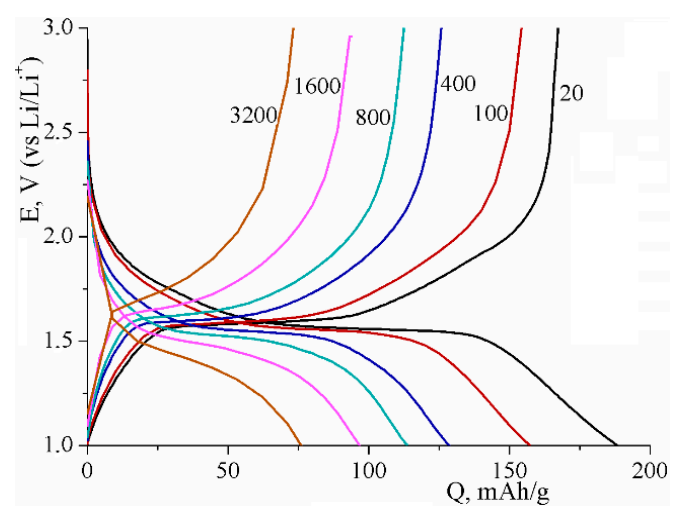

(a)

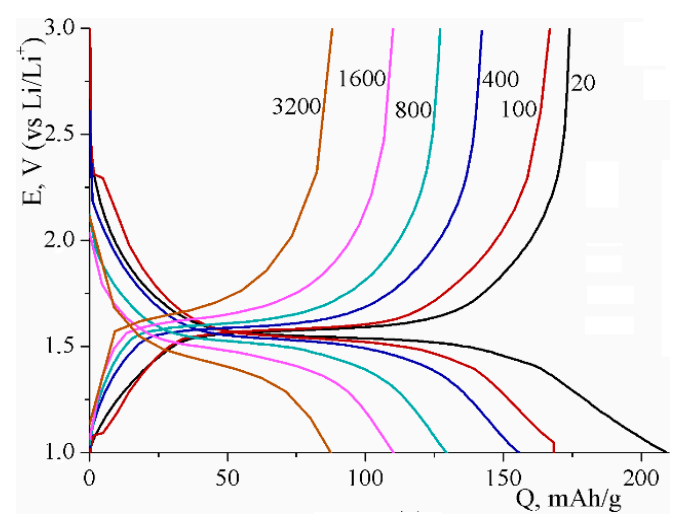

(c)

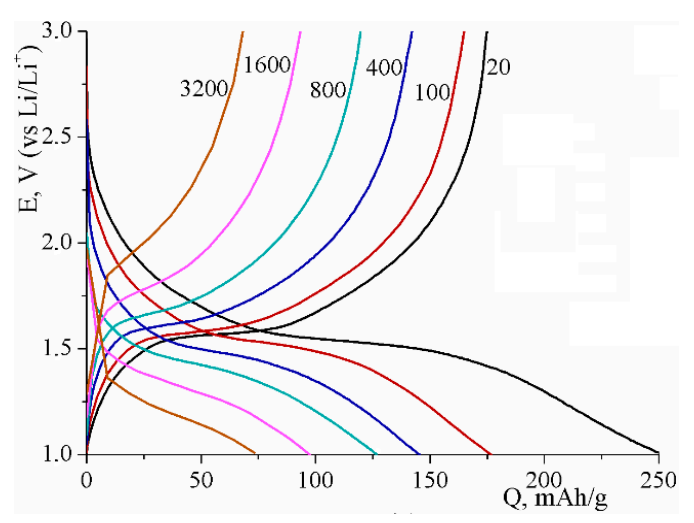

(b)

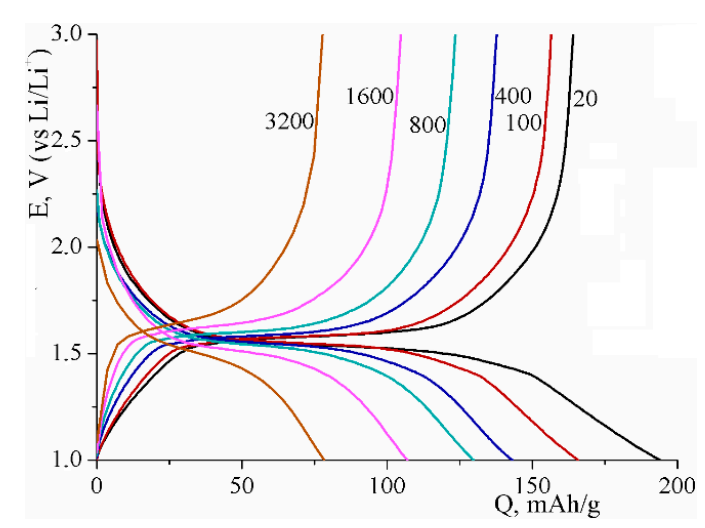

(d)

Figure 4. Charge-discharge curves of the LTO (a), LTO/5\%G_157M (b), LTO/5\%CB (c), and LTO/5\%CR (d) samples. 


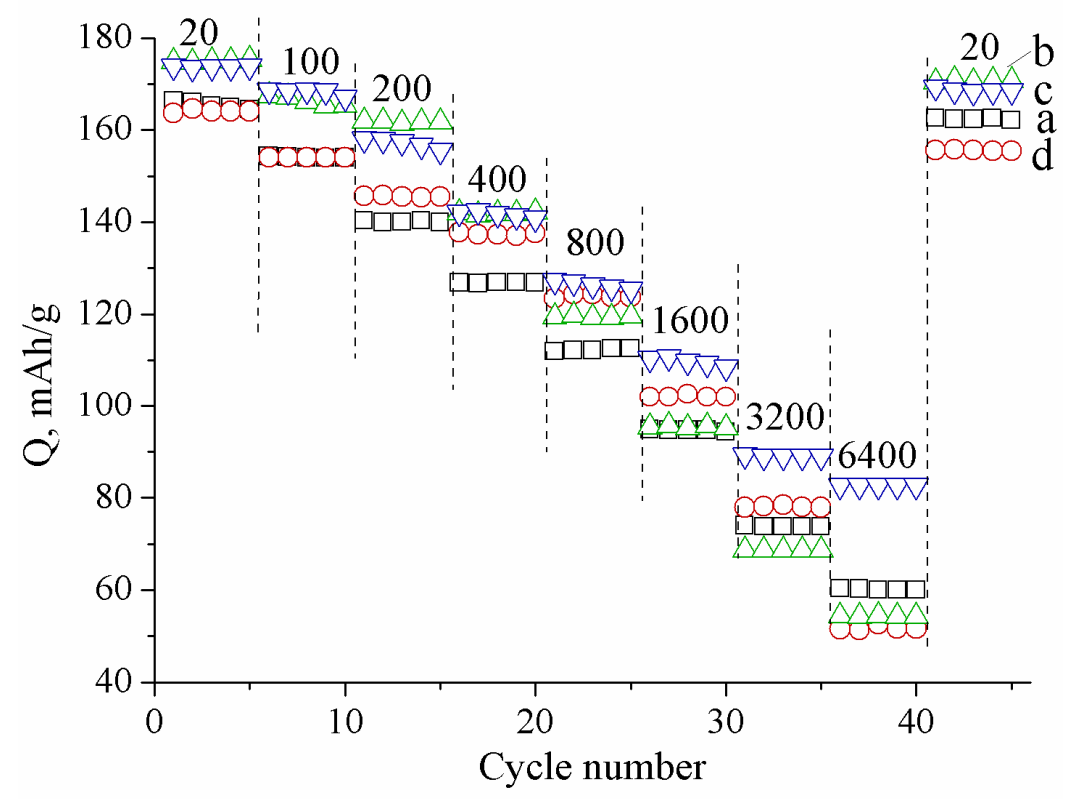

Figure 5. Cycling performance of the LTO (a), LTO/5\%G_157M (b), LTO/5\%CB (c), and LTO/5\%CR (d) samples. The current densities $(\mathrm{mA} / \mathrm{g})$ are shown in the Figure.

Table 3 presents the recently reported electrochemical performance of $\mathrm{Li}_{4} \mathrm{Ti}_{5} \mathrm{O}_{12}$-based composites with various carbon materials. It can be seen that $\mathrm{Li}_{4} \mathrm{Ti}_{5} \mathrm{O}_{12} / 3 \mathrm{D}$ amorphous carbon and $\mathrm{Li}_{4} \mathrm{Ti}_{5} \mathrm{O}_{12} / \mathrm{CNTs}$ composites prepared hydrothermally have the highest capacity at both $0.1 \mathrm{C}$ and $5 \mathrm{C}$ rates $[28,32,37]$. The electrochemical performance of the $\mathrm{LTO} / 5 \% \mathrm{CB}$ electrode prepared in this work is very close to the maximum value at low $C$ rates. At high $C$ rates, it is much better than that of $\mathrm{Li}_{4} \mathrm{Ti}_{5} \mathrm{O}_{12} / \mathrm{C}$ composites, in which pyrolytic carbons were used as carbon sources, and some CNTs- and graphene-based composites (Table 3). Such electrochemical performance can be due to both homogeneous distribution of carbon material, which efficaciously enhances the electronic conductivity of the $\mathrm{Li}_{4} \mathrm{Ti}_{5} \mathrm{O}_{12} / \mathrm{C}$ composite, and its nanostructure, which shortens the $\mathrm{Li}^{+}$-ion pathway.

Table 3. Specific discharge capacities of the $\mathrm{Li}_{4} \mathrm{Ti}_{5} \mathrm{O}_{12} / \mathrm{C}$ composites with various carbon materials.

\begin{tabular}{|c|c|c|}
\hline Composite Material & Synthesis Method (Conditions) & Capacity, mAh/g (C-Rate) \\
\hline $\mathrm{Li}_{4} \mathrm{Ti}_{5} \mathrm{O}_{12} /$ carbon nanotubes $/ \mathrm{C}^{1}[28]$ & Solid state reaction $\left(800^{\circ} \mathrm{C}, 16 \mathrm{~h}, \mathrm{Ar}\right)$ & $167(0.1 C), 151(5 C)$ \\
\hline $\begin{array}{c}\mathrm{Li}_{4} \mathrm{Ti}_{5} \mathrm{O}_{12} / \text { multi-walled carbon } \\
\text { nanotubes [64] }\end{array}$ & Solid state reaction $\left(850^{\circ} \mathrm{C}, 26 \mathrm{~h}\right)$ & $166(0.2 \mathrm{C}), 118(5 \mathrm{C})$ \\
\hline $\mathrm{Li}_{4} \mathrm{Ti}_{5} \mathrm{O}_{12} /$ graphene [65] & $\begin{array}{c}\mathrm{Li}_{4} \mathrm{Ti}_{5} \mathrm{O}_{12}: \text { Hydrothermal }\left(180^{\circ} \mathrm{C}, 24 \mathrm{~h}\right)+\text { calcination } \\
\left(700{ }^{\circ} \mathrm{C}, 8 \mathrm{~h}, \mathrm{Ar}\right) \mathrm{Li}_{4} \mathrm{Ti}_{5} \mathrm{O}_{12} / \text { graphene suspension: } \\
\text { Hydrothermal }\left(120^{\circ} \mathrm{C}, 16 \mathrm{~h}\right)\end{array}$ & $184^{4}(0.1 \mathrm{C}), 102(5 \mathrm{C})$ \\
\hline $\mathrm{Li}_{4} \mathrm{Ti}_{5} \mathrm{O}_{12} /$ carbon nanotubes [37] & Hydrothermal $\left(120^{\circ} \mathrm{C}, 16 \mathrm{~h}\right)+$ calcination $\left(700^{\circ} \mathrm{C}, 6 \mathrm{~h}, \mathrm{Ar}\right)$ & $172(0.1 C), 157(5 C)$ \\
\hline $\mathrm{Li}_{4} \mathrm{Ti}_{5} \mathrm{O}_{12} / 3 \mathrm{D}$ amorphous carbon [32] & Hydrothermal $\left(180^{\circ} \mathrm{C}, 18 \mathrm{~h}\right)+$ calcination $\left(600^{\circ} \mathrm{C}, 3 \mathrm{~h}, \mathrm{Ar}\right)$ & $169(0.2 \mathrm{C}), 159(5 \mathrm{C})$ \\
\hline $\mathrm{Li}_{4} \mathrm{Ti}_{5} \mathrm{O}_{12} / \mathrm{C}^{2}[66]$ & Hydrothermal $\left(100^{\circ} \mathrm{C}, 24 \mathrm{~h}\right)+$ calcination $\left(800^{\circ} \mathrm{C}, 2 \mathrm{~h}, \mathrm{Ar}\right)$ & $146(0.1 \mathrm{C}), 105(5 \mathrm{C})$ \\
\hline $\mathrm{Li}_{4} \mathrm{Ti}_{5} \mathrm{O}_{12} / \mathrm{C}^{3}[67]$ & Hydrothermal $\left(200^{\circ} \mathrm{C}, 36 \mathrm{~h}\right)+$ calcination $\left(700^{\circ} \mathrm{C}, 6 \mathrm{~h}, \mathrm{Ar}\right)$ & $165(0.2 C), 112(3.2 C)$ \\
\hline $\mathrm{Li}_{4} \mathrm{Ti}_{5} \mathrm{O}_{12} /$ reduced graphene oxide [68] & Hydrothermal $\left(180^{\circ} \mathrm{C}, 36 \mathrm{~h}\right)+$ calcination $\left(600^{\circ} \mathrm{C}, 6 \mathrm{~h}, \mathrm{Ar}\right)$ & 168 (0.5C), $138(5 \mathrm{C})$ \\
\hline $\mathrm{Li}_{4} \mathrm{Ti}_{5} \mathrm{O}_{12} /$ carbon nanotubes [69] & Hydrothermal $\left(180^{\circ} \mathrm{C}, 40 \mathrm{~h}\right)+$ calcination $\left(600^{\circ} \mathrm{C}, 6 \mathrm{~h}, \mathrm{~N}_{2}\right)$ & $162(0.5 C), 128(3 C)$ \\
\hline $\mathrm{Li}_{4} \mathrm{Ti}_{5} \mathrm{O}_{12} /$ carbon black (this work) & Hydrothermal $\left(130^{\circ} \mathrm{C}, 12 \mathrm{~h}\right)+$ calcination $\left(400^{\circ} \mathrm{C}, 5 \mathrm{~h}, \mathrm{Ar}\right)$ & $174(0.1 \mathrm{C}), 127(5 \mathrm{C})$ \\
\hline
\end{tabular}

However, only carbon material added during the synthesis of lithium titanate composite is not enough for the successful anode operation. When the electrodes were manufactured without carbon black addition (only the as-prepared samples were used in the cell fabrication), a significant deterioration in the electrochemical properties of the obtained composites was observed over the entire 
range of charge-discharge rates (Figure 6). For example, at a current density of $20 \mathrm{~mA} / \mathrm{g}$, the discharge capacities of the LTO/5\%G_157M and LTO/5\%G_157M composites are 150 and $165 \mathrm{mAh} / \mathrm{g}$ respectively, and significantly decrease with increasing current density.

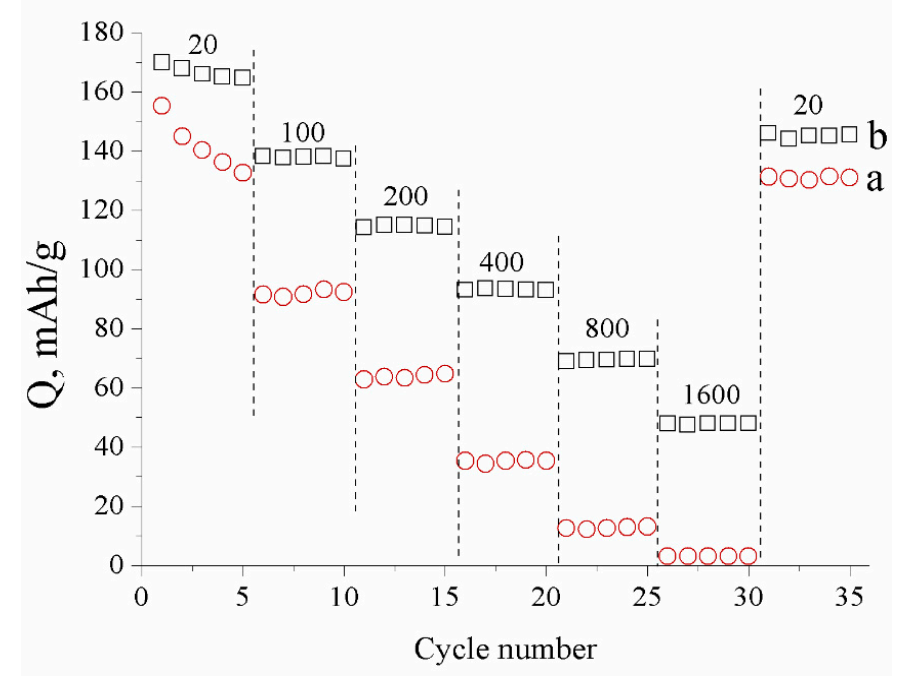

Figure 6. Cycling performance of the LTO/5\%G_157M (a) and LTO/5\%CB (b) composites (electrodes were prepared without addition of carbon black Timcal). The current densities (mA/g) are shown in the Figure.

It seems that a possible solution is to introduce more carbon material at the synthesis stage. However, increasing the carbon material content to $20 \mathrm{wt} . \%$ (to substitute $15 \mathrm{wt} . \%$ carbon black added during electrochemical cell assembly) did not have the expected positive effect. Thus, the addition of 20 wt.\% G_157M, CR, and CB materials results in lower capacities of the obtained composites even at low charge-discharge rates. At a current density of $20 \mathrm{~mA} / \mathrm{g}$, the discharge capacities of the LTO/20\%G_157M, LTO/20\%CR, and LTO/20\%CB composites are 140, 120, and $150 \mathrm{mAh} / \mathrm{g}$, respectively (Figure 7). This is due to a decrease in the lithium titanate content, which is significantly more active in this potential range. Moreover, the degradation of these samples during cycling was somewhat higher.

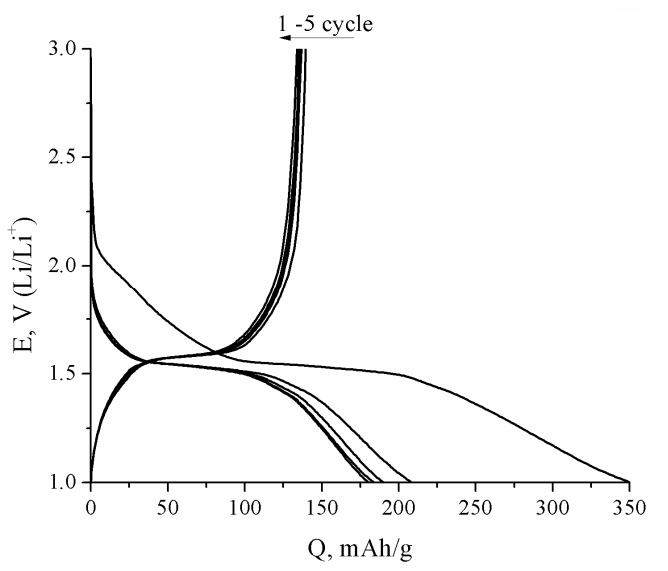

(a)

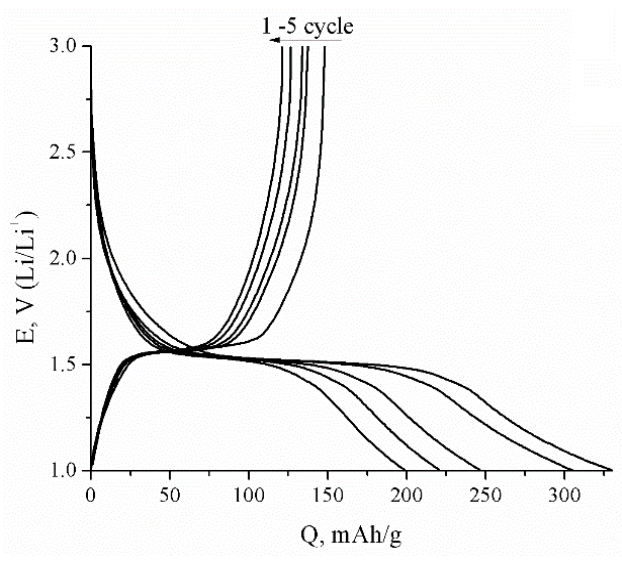

(b)

Figure 7. Cont. 


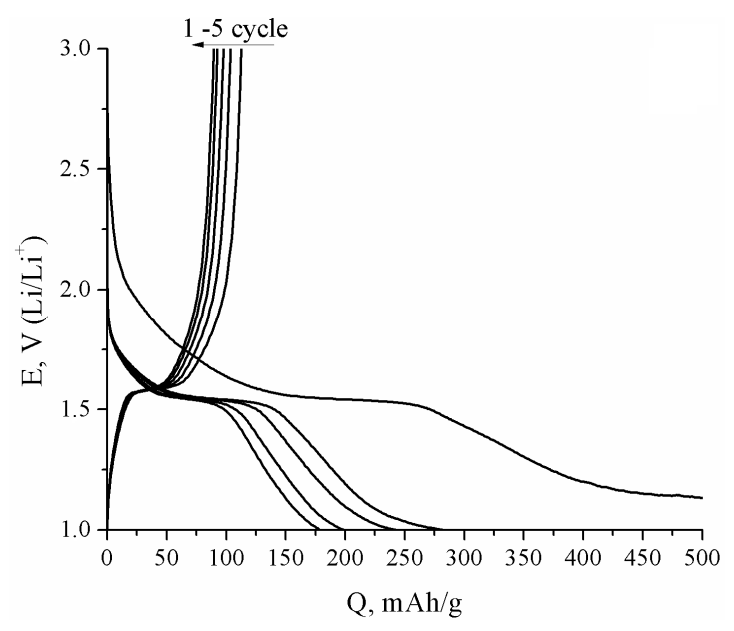

(c)

Figure 7. Charge-discharge curves of the LTO/20\%G_157M (a), LTO/20\%CB (b), and LTO/20\%CR (c) composites. Current density $20 \mathrm{~mA} / \mathrm{g}$.

A comparison of the obtained data shows that the introduction of carbon materials during the LTO synthesis has a positive effect on the electrochemical properties of the obtained composites. However, increasing the specific surface area of carbon materials does not always give better results. Morphology of the obtained samples also plays an important role. The developed inner surface of mesoporous carbon materials, even after functionalization, practically does not interact with lithium titanate and does not increase the rate of transfer processes. Even the presence of 1D carbons in the LTO/G_157M and LTO/CR composites does not have a significant effect, and the LTO/CB composites show the best performance. At the same time, the introduction of a small amount of mesoporous carbon G_157M and carbon black with a functionalized surface can significantly increase the rate capability of the obtained composites, which is very promising for the manufacture of high-power batteries.

\section{Conclusions}

A simple hydrothermal method was successfully developed to synthesize the $\mathrm{Li}_{4} \mathrm{Ti}_{5} \mathrm{O}_{12}$ composites with mesoporous carbon G_157M, carbon replicas (CR), or carbon black. Upon the introduction of carbon materials during synthesis, the morphologies of both the LTO particles and their agglomerates change. The use of carbon materials with a functionalized surface during the synthesis allows for achieving a significant increase in the rate capacity of the obtained composites, especially at high current densities. The LTO/5\%CB composite exhibits the excellent rate performance with a reversible discharge capacity of $68 \mathrm{mAh} / \mathrm{g}(39 \%$ of the theoretical value) at $-50 \mathrm{C}$. Both the content of carbon material and the procedure of the cell fabrication were shown to be important. As is known, carbon black is always used in the preparation of electrodes during cell assembly. It was shown that the use of the same amount of carbon material during the synthesis instead of carbon black does not result in the same electrochemical performance. The obtained composite materials seem to be promising for use as anodes for power lithium-ion battery applications.

Author Contributions: Conceptualization, I.S. and A.Y.; investigation, R.S., N.T., A.K. and T.K.; writing-original draft preparation, I.S., T.K. and R.S.; writing-review and editing, I.S. and A.Y.; project administration, I.S.; funding acquisition, I.S. All authors have read and agreed to the published version of the manuscript.

Funding: This work was supported by the Russian Foundation for Basic Research (grant No. 20-08-00769).

Acknowledgments: The SEM measurements were performed using shared experimental facilities supported by IGIC RAS state assignment.

Conflicts of Interest: The authors declare no conflict of interest. 


\section{References}

1. Ariyoshi, A.K.; Yamato, R.; Ohzuku, T. Zero-strain insertion mechanism of $\mathrm{Li}\left[\mathrm{Li}_{1 / 3} \mathrm{Ti}_{5 / 3}\right] \mathrm{O}_{4}$ for advanced lithium-ion (shuttlecock) batteries. Electrochim. Acta 2005, 51, 1125-1129. [CrossRef]

2. Zhao, B.; Ran, R.; Liu, M.; Shao, Z. A comprehensive review of $\mathrm{Li}_{4} \mathrm{Ti}_{5} \mathrm{O}_{12}$-based electrodes for lithium-ion batteries: The latest advancements and future perspectives. Mater. Sci. Engineer. R 2015, 98, 1-71. [CrossRef]

3. Kim, T.; Song, W.; Son, D.-Y.; Ono, L.K.; Qi, Y. Lithium-ion batteries: Outlook on present, future, and hybridized technologies. J. Mater. Chem. A 2019, 7, 2942-2964. [CrossRef]

4. Winter, M.; Besenhard, J.O.; Spahr, M.E.; Novák, P. Insertion Electrode Materials for Rechargeable Lithium Batteries. Adv. Mater. 1998, 10, 725-763. [CrossRef]

5. Tarascon, J.-M.; Armand, M. Issues and challenges facing rechargeable lithium batteries. Nature 2001, 414, 359-367. [CrossRef]

6. Vijayakumar, M.; Kerisit, S.; Rosso, K.M.; Burton, S.D.; Sears, J.A.; Yang, Z.; Graff, G.L.; Liu, J.; Hu, J. Lithium diffusion in $\mathrm{Li}_{4} \mathrm{Ti}_{5} \mathrm{O}_{12}$ at high temperatures. J. Power Sources 2011, 196, 2211-2220. [CrossRef]

7. Michalska, M.; Krajewski, M.; Ziolkowska, D.; Hamankiewicz, B.; Andrzejczuk, M.; Lipinska, L.; Korona, K.P.; Czerwinski, A. Influence of milling time in solid-state synthesis on structure, morphology and electrochemical properties of $\mathrm{Li}_{4} \mathrm{Ti}_{5} \mathrm{O}_{12}$ of spinel structure. Powder Technol. 2014, 266, 372-377. [CrossRef]

8. Zhu, Y.-R.; Yin, L.-C.; Yi, T.-F.; Liu, H.; Xie, Y.; Zhu, R.-S. Electrochemical performance and lithium-ion intercalation kinetics of submicron-sized $\mathrm{Li}_{4} \mathrm{Ti}_{5} \mathrm{O}_{12}$ anode material. J. Alloys Compd. 2013, 547, $107-112$. [CrossRef]

9. Chauque, S.; Oliva, F.Y.; Visintin, A.; Barraco, D.; Leiva, E.P.M.; Cámara, O.R. Lithium titanate as anode material for lithium ion batteries: Synthesis, post-treatment and its electrochemical response. J. Electroanal. Chem. 2017, 799, 142-155. [CrossRef]

10. Gu, Y.-J.; Guo, Z.; Liu, H.-Q. Structure and electrochemical properties of $\mathrm{Li}_{4} \mathrm{Ti}_{5} \mathrm{O}_{12}$ with $\mathrm{Li}$ excess as an anode electrode material for Li-ion batteries. Electrochim. Acta 2014, 123, 576-581. [CrossRef]

11. Han, S.-W.; Ryu, J.H.; Jeong, J.; Yoon, D.-H. Solid-state synthesis of $\mathrm{Li}_{4} \mathrm{Ti}_{5} \mathrm{O}_{12}$ for high power lithium ion battery applications. J. Alloys Compd. 2013, 570, 144-149. [CrossRef]

12. Wang, Y.; Zhou, A.; Dai, X.; Feng, L.; Li, J.; Li, J. Solid-state synthesis of submicron-sized $\mathrm{Li}_{4} \mathrm{Ti}_{5} \mathrm{O}_{12} / \mathrm{Li}_{2} \mathrm{TiO}_{3}$ composites with rich grain boundaries for lithium ion batteries. J. Power Sources 2014, 266, 114-120. [CrossRef]

13. Zhang, E.; Zhang, H. Hydrothermal synthesis of $\mathrm{Li}_{4} \mathrm{Ti}_{5} \mathrm{O}_{12}-\mathrm{TiO}_{2}$ composites and $\mathrm{Li}_{4} \mathrm{Ti}_{5} \mathrm{O}_{12}$ and their applications in lithium-ion batteries. Ceram. Int. 2019, 45, 7419-7426. [CrossRef]

14. Zhang, W.; Li, J.; Guan, Y.; Jin, Y.; Zhu, W.; Guo, X.; Qiu, X. Nano- $\mathrm{Li}_{4} \mathrm{Ti}_{5} \mathrm{O}_{12}$ with high rate performance synthesized by a glycerol assisted hydrothermal method. J. Power Sources 2013, 243, 661-667. [CrossRef]

15. Yi, T.-F.; Wei, T.-T.; Li, Y.; He, Y.-B.; Wang, Z.-B. Efforts on enhancing the Li-ion diffusion coefficient and electronic conductivity of titanate-based anode materials for advanced Li-ion batteries. Energy Storage Mater. 2020, 26, 165-197. [CrossRef]

16. Liu, Y.; Yan, X.; Xu, B.; Lan, J.; Yu, Y.; Yang, X.; Lin, Y.; Nan, C. $\mathrm{Li}_{4} \mathrm{Ti}_{5} \mathrm{O}_{12}$ nanosheets assembled in tubular architecture for lithium storage. Chem. Eng. J. 2019, 361, 1371-1380. [CrossRef]

17. Cao, N.; Song, Z.; Liang, Q.; Gao, X.; Qin, X. Hierarchical $\mathrm{Li}_{4} \mathrm{Ti}_{5} \mathrm{O}_{12} / \mathrm{C}$ composite for lithium-ion batteries with enhanced rate performance. Electrochim. Acta 2017, 235, 200-209. [CrossRef]

18. Zou, S.; Wang, G.; Zhang, Y.; Xue, C.; Chen, H.; Yang, G.; Nan, H.; Wei, H.; Lin, H. Nano-structure and characterization of carbon composite with $\mathrm{Al}^{3+}$ and $\mathrm{Mn}^{4+}$ co-doped $\mathrm{Li}_{4} \mathrm{Ti}_{5} \mathrm{O}_{12}$ as anodes for Li-ion batteries. J. Alloy Compd. 2020, 816, 152609. [CrossRef]

19. Chang-Jian, C.-W.; Ho, B.-C.; Chung, C.-K.; Chou, J.-A.; Chung, C.-L.; Huang, J.-H.; Huang, J.-H.; Hsiao, Y.-S. Doping and surface modification enhance the applicability of $\mathrm{Li}_{4} \mathrm{Ti}_{5} \mathrm{O}_{12}$ microspheres as high-rate anode materials for lithium ion batteries. Ceram. Int. 2018, 44, 23063-23072. [CrossRef]

20. Stenina, I.A.; Sobolev, A.N.; Yaroslavtsev, S.A.; Rusakov, V.S.; Kulova, T.L.; Skundin, A.M.; Yaroslavtsev, A.B. Influence of iron doping on structure and electrochemical properties of $\mathrm{Li}_{4} \mathrm{Ti}_{5} \mathrm{O}_{12}$. Electrochim. Acta 2016, 219, 524-530. [CrossRef]

21. Chen, Y.; Qian, C.; Zhang, P.; Zhao, R.; Lu, J.; Chen, M. Fluoride doping $\mathrm{Li}_{4} \mathrm{Ti}_{5} \mathrm{O}_{12}$ nanosheets as anode materials for enhanced rate performance of lithium-ion batteries. J. Electroanal. Chem. 2018, 815, 123-129. [CrossRef] 
22. Hsiao, K.C.; Liao, S.C.; Chen, J.M. Microstructure effect on the electrochemical property of $\mathrm{Li}_{4} \mathrm{Ti}_{5} \mathrm{O}_{12}$ as an anode material for lithium-ion batteries. Electrochim. Acta 2008, 53, 7242-7247. [CrossRef]

23. Wang, Y.; Zhu, W. Micro/nano-structured $\mathrm{Li}_{4} \mathrm{Ti}_{5} \mathrm{O}_{12}$ as high rate anode material for lithium ion batteries. Solid State Ionics 2020, 349, 115297. [CrossRef]

24. Wang, L.; Yue, S.; Zhang, Q.; Zhang, Y.; Li, Y.R.; Lewis, C.S.; Takeuchi, K.J.; Marschilok, A.C.; Takeuchi, E.S.; Wong, S.S. Morphological and Chemical Tuning of High-Energy-Density Metal Oxides for Lithium Ion Battery Electrode Applications. ACS Energy Lett. 2017, 2, 1465-1478. [CrossRef]

25. Yue, J.; Badaczewski, F.M.; Voepel, P.; Leichtweiß, T.; Mollenhauer, D.; Zeier, W.G.; Smarsly, B.M. Critical Role of the Crystallite Size in Nanostructured $\mathrm{Li}_{4} \mathrm{Ti}_{5} \mathrm{O}_{12}$ Anodes for Lithium-Ion Batteries. ACS Appl. Mater. Interfaces 2018, 10, 22580-22590. [CrossRef] [PubMed]

26. Ge, H.; Hao, T.; Osgood, H.; Zhang, B.; Chen, L.; Cui, L.; Song, X.-M.; Ogoke, O.; Wu, G. Advanced Mesoporous Spinel $\mathrm{Li}_{4} \mathrm{Ti}_{5} \mathrm{O}_{12} / \mathrm{rGO}$ Composites with Increased Surface Lithium Storage Capability for High-Power Lithium-Ion Batteries. ACS Appl. Mater. Interfaces 2016, 8, 9162-9169. [CrossRef] [PubMed]

27. Nugroho, A.; Chung, K.Y.; Kim, J. A Facile Supercritical Alcohol Route for Synthesizing Carbon Coated Hierarchically Mesoporous $\mathrm{Li}_{4} \mathrm{Ti}_{5} \mathrm{O}_{12}$ Microspheres. J. Phys. Chem. C 2014, 118, 183-193. [CrossRef]

28. Wang, Z.; Wang, Z.; Peng, W.; Guo, H.; Li, X. Li $\mathrm{Li}_{4} \mathrm{Ti}_{5} \mathrm{O}_{12}$ co-modified with carbon nanotubes and pyrolytic carbon as an advanced anode material for lithium-ion batteries. Mater. Lett. 2014, 137, 413-416. [CrossRef]

29. Stenina, I.A.; Yaroslavtsev, A.B. Nanomaterials for lithium-ion batteries and hydrogen energy. Pure Appl. Chem. 2017, 89, 1185-1194. [CrossRef]

30. Ho, C.-K.; Li, C.-Y.V.; Deng, Z.; Chan, K.-Y.; Yung, H.; Yang, C. Hierarchical macropore-mesoporous shell carbon dispersed with $\mathrm{Li}_{4} \mathrm{Ti}_{5} \mathrm{O}_{12}$ for excellent high rate sub-freezing Li-ion battery performance. Carbon 2019, 145, 614-621. [CrossRef]

31. Zhang, F.; Yi, F.; Meng, T.; Gao, A.; Shu, D.; Chen, H.; Cheng, H.; Zhou, X. In Situ Supramolecular Self-Assembly Assisted Synthesis of $\mathrm{Li}_{4} \mathrm{Ti}_{5} \mathrm{O}_{12}$-Carbon-Reduced Graphene Oxide Microspheres for Lithium-Ion Batteries. ACS Sustain. Chem. Eng. 2019, 7, 916-924. [CrossRef]

32. Yao, N.Y.; Liu, H.K.; Liang, X.; Sun, Y.; Feng, X.Y.; Chen, C.H.; Xiang, H.F. $\mathrm{Li}_{4} \mathrm{Ti}_{5} \mathrm{O}_{12}$ nanosheets embedded in three-dimensional amorphous carbon for superior-rate battery applications. J. Alloy Compd. 2019, 771, 755-761. [CrossRef]

33. Kellerman, D.G.; Gorshkov, V.S.; Shalaeva, E.V.; Tsaryev, B.A.; Vovkotrub, E.G. Structure peculiarities of carbon-coated lithium titanate: Raman spectroscopy and electron microscopic study. Solid State Sci. 2012, 14, 72-79. [CrossRef]

34. Wei, A.; Li, W.; Bai, X.; Zhang, L.; Liu, Z.; Wang, Y. A facile one-step solid-state synthesis of a $\mathrm{Li}_{4} \mathrm{Ti}_{5} \mathrm{O}_{12} /$ graphene composite as an anode material for high-power lithium-ion batteries. Solid State Ionics 2019, 329, 110-118. [CrossRef]

35. Yan, H.; Yao, W.; Fan, R.; Zhang, Y.; Luo, J.; Xu, J. Mesoporous Hierarchical Structure of $\mathrm{Li}_{4} \mathrm{Ti}_{5} \mathrm{O}_{12} / \mathrm{Graphene}$ with High Electrochemical Performance in Lithium-Ion Batteries. ACS Sustain. Chem. Eng. 2018, 6, 11360-11366. [CrossRef]

36. Liu, J.; Wei, A.X.; Chen, M.; Xia, X. Rational synthesis of $\mathrm{Li}_{4} \mathrm{Ti}_{5} \mathrm{O}_{12} / \mathrm{N}-\mathrm{C}$ nanotube arrays as advanced high-rate electrodes for lithium-ion batteries. J. Mater. Chem. A 2018, 6, 3857-3863. [CrossRef]

37. Zhang, P.; Chen, M.; Shen, X.; Wu, Q.; Zhang, X.; Huan, L.; Diao, G. Preparation of $\mathrm{Li}_{4} \mathrm{Ti}_{5} \mathrm{O}_{12}$ nanosheets/carbon nanotubes composites and application of anode materials for lithium-ion batteries. Electrochim. Acta 2016, 204, 92-99. [CrossRef]

38. Ni, H.F.; Fan, L.Z. Nano- $\mathrm{Li}_{4} \mathrm{Ti}_{5} \mathrm{O}_{12}$ anchored on carbon nanotubes by liquid phase deposition as anode material for high rate lithium-ion batteries. J. Power Sources 2012, 214, 195-199. [CrossRef]

39. Lan, C.-K.; Bao, Q.; Huang, Y.-H.; Duh, J.-G. Embedding nano-Li $\mathrm{T}_{4} \mathrm{Ti}_{5} \mathrm{O}_{12}$ in hierarchical porous carbon matrixes derived from water soluble polymers for ultra-fast lithium ion batteries anodic material. J. Alloy Compd. 2016, 673, 336-348. [CrossRef]

40. Ni, D.; Sun, W.; Xie, L.; Fan, Q.; Wang, Z.; Sun, K. Bismuth oxyfluoride@CMK-3 nanocomposite as cathode for lithium ion batteries. J. Power Sources 2018, 374, 166-174. [CrossRef]

41. Ryoo, R.; Joo, S.H.; Kruk, M.; Jaroniec, M. Ordered mesoporous carbons. Adv. Mater. 2001, 13, 677-681. [CrossRef] 
42. Lu, P.; Sun, Y.; Xiang, H.F.; Liang, X.; Yu, Y. 3D amorphous carbon with controlled porous and disordered structures as a high-rate anode material for sodium ion batteries. Adv. Energy Mater. 2017, 8, 1702434. [CrossRef]

43. Saikia, D.; Wang, T.-H.; Chou, C.-J.; Fang, J.; Tsai, L.-D.; Kao, H.-M. A comparative study of ordered mesoporous carbons with different pore structures as anode materials for lithium-ion batteries. RSC Adv. 2015, 5, 42922-42930. [CrossRef]

44. Castro-Muñiz, A.; Lorenzo-Fierro, S.; Martínez-Alonso, A.; Tascón, J.M.D.; Fierro, V.; Suárez-García, F.; Paredes, J.I. Ordered mesoporous carbons obtained from low-value coal tar products for electrochemical energy storage and water remediation. Fuel Process. Technol. 2019, 196, 106152. [CrossRef]

45. Dongil, A.B.; Bachiller-Baeza, B.; Guerrero-Ruiz, A.; Rodríguez-Ramos, I.; Martínez-Alonso, A.; Tascón, J.M.D. Surface chemical modifications induced on high surface area graphite and carbon nanofibers using different oxidation and functionalization treatments. J. Colloid Interface Sci. 2011, 355, 179-189. [CrossRef] [PubMed]

46. Mironova, E.Y.; Ermilova, M.M.; Efimov, M.N.; Orekhova, N.V.; Yaroslavtsev, A.B. Detonation nanodiamonds as catalysts of steam reforming of ethanol. Russ. Chem. Bull. 2013, 62, 2317-2321. [CrossRef]

47. Marciniak, M.; Goscianska, J.; Frankowski, M.; Pietrzak, R. Optimal synthesis of oxidized mesoporous carbons for the adsorption of heavy metal ions. J. Mol. Liq. 2019, 276, 630-637. [CrossRef]

48. Moreno-Tovar, R.; Terrés, E.; Rangel-Mendez, R.J. Oxidation and EDX elemental mapping characterization of an ordered mesoporous carbon: $\mathrm{Pb}$ (II) and Cd(II) removal. Appl. Surf. Sci. 2014, 303, 373-380. [CrossRef]

49. Solyanikova, A.S.; Chayka, M.Y.; Boryak, A.V.; Kravchenko, T.A.; Glotov, A.V.; Ponomarenko, I.V.; Kirik, S.D. Composite electrodes of electrochemical capacitors based on carbon materials with different structure. Russ. J. Electrochem. 2014, 50, 419-428. [CrossRef]

50. Stenina, I.A.; Kulova, T.L.; Skundin, A.M.; Yaroslavtsev, A.B. Effects of carbon coating from sucrose and PVDF on electrochemical performance of $\mathrm{Li}_{4} \mathrm{Ti}_{5} \mathrm{O}_{12} / \mathrm{C}$ composites in different potential ranges. J. Solid State Electrochem. 2018, 22, 2631-2639. [CrossRef]

51. Ferrari, A.C.; Robertson, J. Interpretation of Raman spectra of disordered and amorphous carbon. Phys. Rev. B 2000, 61, 14095-14107. [CrossRef]

52. Baddour-Hadjean, R.; Pereira-Ramo, J.-P. Raman Microspectrometry Applied to the Study of Electrode Materials for Lithium Batteries. Chem. Rev. 2010, 110, 1278-1319. [CrossRef] [PubMed]

53. Leonidov, I.A.; Leonidova, O.N.; Perelyaeva, L.A.; Samigullina, R.F.; Kovyazina, S.A.; Patrakeev, M.V. Structure, Ionic Conduction, and Phase Transformations in Lithium Titanate $\mathrm{Li}_{4} \mathrm{Ti}_{5} \mathrm{O}_{12}$. Phys. Solid State 2003, 45, 2183-2188. [CrossRef]

54. Stenina, I.A.; Sobolev, A.N.; Kuz'mina, A.A.; Kulova, T.L.; Skundin, A.M.; Tabachkova, N.Y.; Yaroslavtsev, A.B. Electrochemical properties of $\mathrm{Li}_{4} \mathrm{Ti}_{5} \mathrm{O}_{12} / \mathrm{C}$ and $\mathrm{Li}_{4} \mathrm{Ti}_{5} \mathrm{O}_{12} / \mathrm{C} / \mathrm{Ag}$ nanomaterials. Inorg. Mater. 2017, 53, 1039-1045. [CrossRef]

55. Figueiredo, J.L.; Pereira, M.F.R.; Freitas, M.M.A.; Órfão, J.J.M. Modification of the surface chemistry of activated carbons. Carbon 1999, 37, 1379-1389. [CrossRef]

56. Kohl, S.; Drochner, A.; Vogel, H. Quantification of oxygen surface groups on carbon materials via diffuse reflectance FT-IR spectroscopy and temperature programmed desorption. Catal. Today 2010, 150, 67-70. [CrossRef]

57. Mironova, E.Y.; Ermilova, M.M.; Orekhova, N.V.; Muraviev, D.N.; Yaroslavtsev, A.B. Production of high purity hydrogen by ethanol steam reforming in membrane reactor. Catal. Today 2014, 236, 64-69. [CrossRef]

58. Biniak, S.; Trykowski, G.; Walczyk, M.; Richert, M. Thermo-Chemical Modification of Low-Dimensional Carbons: An Infrared Study. J. Appl. Spectrosc. 2016, 83, 580-585. [CrossRef]

59. Janus, P.; Janus, R.; Kuśtrowski, P.; Jarczewski, S.; Wach, A.; Silvestre-Albero, A.M.; Rodríguez-Reinoso, F. Chemically activated poly(furfuryl alcohol)-derived CMK-3 carbon catalysts for the oxidative dehydrogenation of ethylbenzene. Catal. Today 2014, 235, 201-209. [CrossRef]

60. Peled, E.; Golodnitsky, D.; Ulus, A.; Yufit, V. Effect of carbon substrate on SEI composition and morphology. Electrochim. Acta 2004, 50, 391-395. [CrossRef]

61. Zheng, X.; Shi, Q.; Wang, Y.; Battaglia, V.S.; Huang, Y.; Zheng, H. The role of carbon bond types on the formation of solid electrolyte interphase on graphite surfaces. Carbon 2019, 148, 105-114. [CrossRef]

62. Wang, R.; Li, X.; Wang, Z.; Zhang, H. Electrochemical analysis graphite/electrolyte interface in lithium-ion batteries: p-Toluenesulfonyl isocyanate as electrolyte additive. Nano Energy 2017, 34, 131-140. [CrossRef] 
63. Xu, G.; Han, P.; Dong, S.; Liu, H.; Cui, G.; Chen, L. $\mathrm{Li}_{4} \mathrm{Ti}_{5} \mathrm{O}_{12}$-based energy conversion and storage systems: Status and prospects. Coord. Chem. Rev. 2017, 34315, 139-184. [CrossRef]

64. Chaturvedi, P.; Kanagaraj, A.B.; Al Nahyan, M.S.; Al Shibli, H.; Ashoor, A.A.; Fadaq, H.; Al Dahmani, S.; Choi, D.S. Electrical and electrochemical properties of carbon nanotube-based free standing LTO electrodes for current collector-free Li-ion batteries. Curr. Appl. Phys. 2019, 19, 1150-1155. [CrossRef]

65. Zhun, J.; Duan, R.; Zhang, Y.; Zhu, J. A facial solvothermal reduction route for the production of $\mathrm{Li}_{4} \mathrm{Ti}_{5} \mathrm{O}_{12}$ /graphene composites with enhanced electrochemical performance. Ceram. Int. 2016, 42, 334-340.

66. Liu, J.; Shen, Y.; Chen, L.; Wang, Y.; Xia, Y. Carbon coated $\mathrm{Li}_{4} \mathrm{Ti}_{5} \mathrm{O}_{12}$ nanowire with high electrochemical performance under elevated temperature. Electrochim. Acta 2015, 156, 38-44. [CrossRef]

67. Liu, K.; Cui, J.; Yin, J.; Man, J.; Cui, Y.; Wen, Z.; Sun, J. Ultra-long life core-shell structure Li4Ti5O12/C nanocomposite anode materials for lithium ion batteries. J. Alloy Compd. 2018, 765, 229-235. [CrossRef]

68. Zhang, J.; Cai, Y.; Yao, J. Graphene oxide-confined synthesis of $\mathrm{Li}_{4} \mathrm{Ti}_{5} \mathrm{O}_{12}$ microspheres as high-performance anodes for lithium ion batteries. Electrochim. Acta 2015, 165, 422-429. [CrossRef]

69. Zhu, Y.-R.; Wang, P.; Yi, T.-F.; Deng, L.; Xie, Y. Improved high-rate performance of $\mathrm{Li}_{4} \mathrm{Ti}_{5} \mathrm{O}_{12} /$ carbon nanotube nanocomposite anode for lithium-ion batteries. Solid State Ionics 2015, 276, 84-89. [CrossRef]

(C) 2020 by the authors. Licensee MDPI, Basel, Switzerland. This article is an open access article distributed under the terms and conditions of the Creative Commons Attribution (CC BY) license (http://creativecommons.org/licenses/by/4.0/). 